\title{
PERANCANGAN APLIKASI KASIR POINT OF SALES BERBASIS ANDROID MENGGUNAKAN METODE RAPID APPLICATION DEVELOPMENT UNTUK USAHA RETAIL
}

\section{ANDROID BASED POINT OF SALES FLASH APPLICATION DESIGN USING RAPID APPLICATION DEVELOPMENT METHOD FOR RETAIL BUSINESS}

\author{
Iskandar $^{1 *}$, Umar Tsani Abdurrahman ${ }^{1}$ \\ 1* Program Studi Teknik Informatika, Sekolah Tinggi Teknologi Muhammadiyah Cileungsi. Bogor, Jawa
} Barat, Indonesia 16820.

\section{Informasi Artikel Article History: \\ Submission: 29-11-2020 \\ Revised: 07-12-2020 \\ Accepted: 21-12-2020 \\ Kata Kunci: \\ Android, Point of Sales, RAD, Bluetooth Printer, Gerai \\ Keywords: \\ Android, Point of Sales, RAD, Bluetooth Printer, Gerai}

\section{* Korespondensi:}

iskandar@sttmcileungsi.ac.id

\begin{abstract}
Abstrak
Gerai merupakan tempat penjual menjajakan makanan atau minuman baik makanan ringan atau makanan berat untuk keperluan pangan sehari-hari. Dalam proses transaksi penjualan sebuah gerai dilakukan belum memanfaatkan teknologi seperti terdapat sebuah kasir dengan menggunakan sistem komputer. Sehingga dengan tidak menggunakan sebuah sistem kasir yang terkomputerisasi ini pengelola gerai banyak menemukan kendala dalam proses perhitungan dalam proses transaksinya diantaranya kesalahan hitung dan proses rekap transaksi yang relatif lama karena haru menghitung ulang setelah gerai tutup jualan sehingga perlu memerlukan kerja extra. Dalam mengatasi masalah tersebut perlu adanya aplikasi kasir untuk mengatasi kesalahan transaksi dalam perhitungan dan proses rekapitulasi, dalam analisis dan perancangan menggunakan metode UML sedangkan metode pengembangan perangkat lunak menggunakan metode Rapid Application Development (RAD) setelah dilakukan pengujian pada aplikasi kasir berbasis android tersebut menghasilkan performance yang cukup baik sehingga dapat digunakan untuk transaksi penjualan oleh pengelola gerai.

\begin{tabular}{l} 
Abstract \\
\hline An outlet is a place for sellers to sell food or drinks, both snacks and \\
heavy meals for daily food needs. In the process of selling an outlet, the \\
transaction is carried out without utilizing technology, such as a cashier \\
using a computer system. So that by not using a computerized cashier \\
system, store managers find many obstacles in the calculation process \\
in the transaction process, including calculation errors and a relatively \\
long transaction recap process because they have to recalculate after \\
the outlet closes, so it requires extra work. In overcoming this problem, \\
it is necessary to have a cashier application to overcome transaction \\
errors in the calculation and recapitulation process, in the analysis and \\
design using the UML method, while the software development method \\
uses the Rapid Application Development (RAD) method after testing the
\end{tabular}
\end{abstract}


Android-based cashier application produces good performance. Good enough so that it can be used for sales transactions by outlet managers.

\section{PENDAHULUAN.}

Gerai merupakan tempat jualan makanan bisa menjual kebutuhan pokok untuk makanan utama atau menjual lauk pauk untuk kebutuhan makan atau juga untuk menjual cemilan yang bukan menjadi makanan pokok utama warga. Salah satu gerai penjualan makanan favorit warga adalah menu ayam geprek dengan kombinasi menu utama adalah ayam geprek original, ayam geprek mozarella, ayam geprek keju dan ayam geprek mie. ayam geprek merupakan makanan yang mudah didapat dan harga relatif murah tetapi memiliki sensasi pedas yang menyegarkan bagi orang yang menyukainya, terutama bagi anak-anak dan ibu yang suka dengan makanan pedas dari olahan ayam yang digoreng setelah diberikan tepung yang sudah diracik bumbu rempah.

Selain harga yang murah dan variasi menu yang ada serta sensasi pedasnya gerai ayam geprek ini banyak didatangi oleh pembeli yang transit pulang kerja dari lokasi jakarta dan sekitarnya maupun ada juga dari para pendatang yang melakukan perjalanan ke lokasi sekitar penjual. Kebanyakan gerai penjual ayam geprek ini belum memiliki sistem penjualan kasir secara digital dengan menggunakan mesin printer[1], tetapi masih dilakukan rekap pada kertas manual pada rekap penjualan dari setiap pelanggan nya.

Dalam melayani pelanggannya penjual ayam geprek ini dengan cara pelanggan menuju gerai dan memesan aneka olahan makanan dari gerai, kemudian setelah selesai pegawai melayani makanan yang dipesan pelanggan juga dapat memesan makan di tempat maupun dibawa pulang. Kemudian pegawai akan menghitung total dari jenis makanan yang dipesan dan dilakukan pembayaran. Setelah dilakukan pembayaran maka pelanggan boleh membawa pulang bagi yang memesan makanan. Pegawai gerai akan mencatat jenis makanan yang sudah dibeli oleh pelanggan pada form catatan penjualan harian pada hari itu.

Form catatan penjualan itu akan dijadikan rekapitulasi penjualan. Dalam rekapitulasi diketahui jenis makanan apa yang laku pada hari tersebut. Setelah direkap selanjutnya dikumpulkan dan dilakukan inputan ulang pada aplikasi pengolah angka. Dari proses pencatatan yang ada, pegawai sering melakukan kesalahan karena salah mencatat, karena lupa mencatat terhadap jenis makanan apa yang sudah dijual, sehingga laporan rekap harian sering terjadi ketidakcocokan dengan perhitungan pendapatan. Dalam melakukan penelitian ini mengacu pada penelitian-penelitian sebelumnya sebagai bahan atau roadmap dalam penelitian. Adapun penelitian yang ada kaitanya yaitu Penelitian[2], pada tahun 2017 dengan judul rancang bangun aplikasi android (point of sales) kafe untuk kasir portable dan bluetooth printer.

Dimana permasalahannya terjadi dalam proses rekapitulasi penjualan harus di entri-kan lagi setelah selesai penjualan hal ini akan menambah pekerjaan baru. Penelitian yang dilakukan[3], pada tahun 2019 dilakukan penelitian dengan judul rancang bangun aplikasi Point of Sales berbasis Android (studi kasus pada sekolah darma yudha) dalam penelitiannya menghasilkan aplikasi tablet android yang dapat membantu transaksi penjualan dan membuat rekapitulasi laporan dan transaksi di kantin dan aplikasi tersebut ditambahkan dengan fitur pencetakan struk untuk pelanggan. 
Penelitian yang dilakukan [4], pada tahun 2020 melakukan penelitian dengan judul rancang bangun sistem informasi pos (point of sales) menggunakan konsep pemrograman berorientasi objek. Dari hasil penelitian mengatakan bahwa dengan sistem pos dapat melakukan penjumlahan dan pengurangan dengan lebih tepat, cepat dan akurat sehingga dapat terhindar dari resiko kesalahan perhitungan keuangan, pendataan barang dan pencairan stok barang dan dapat melakukan pelaporan dengan lebih baik dan efisien.

\section{METODE.}

Dalam penelitian untuk perancangan perangkat lunak aplikasi kasir. Metode pengembagannya menggunakan Rapid Application Development (RAD). Ada beberapa fase menggunakan metode RAD.

a. Fase perencanaan.

Dalam fase ini dilakukan dengan mengidentifikasi fungsi-fungsi sistem dan informasi yang dibutuhkan oleh pengelola gerai ayam geprek di wilayah jonggol.

b. Fase desain.

Dalam fase ini dilakukan workshop untuk melakukan perancangan dan mendesain layout antarmuka untuk keperluan user pada aplikasi kasir.

c. Fase implementasi.

Dalam fase ini analisis dan pengguna bekerja sama dalam merancang fungsi-fungsi untuk keperluan dalam aplikasi kasir baik secara teknis maupun non teknis dan selanjutnya hasil rancangan diadakan pengujian dan digunakan sebagai uji coba oleh pengguna aplikasi kasir.

\subsection{Gerai.}

Menurut kamus KBBI bahwa gerai adalah tempat menyajikan makanan atau kue-kue biasanya disajikan dengan cara swalayan. Biasanya dapat menyajikan makanan dan minuman bisa untuk dimakan langsung atau untuk dibawa pulang.

\subsection{Point off sales.}

Sebuah transaksi penjualan dengan menyediakan fasilitas cetak atau print dari bukti pesanan pelanggan baik menggunakan cetakan berupa mesin drawer, cash drawer atau thermal printer dalam melayani pelanggan nya[1]. Bentuk layanannya lainya bisa berupa manajemen pada pelanggan, manajemen produk, interface transaksi dengan pelanggan dan rekapitulasi laporan secara komputerisasi baik berbasis web based maupun mobile.

\subsection{Android.}

Sistem Android[5] merupakan sebuah sistem operasi yang berbasis linux yang dirancang untuk user atau penggunanya sebagai perangkat mobile dengan fitur layar sentuh yang diaplikasikan pada perangkat smartphone, komputer tablet atau sejenisnya. Dimana sistem android adalah jenis dari perangkat lunak open source yang dapat dikembangkan oleh setiap pengembang perangkat lunak.

\subsection{SQLite database.}

Sistem database SQLite[6], merupakan sistem database embedded yang digunakan dalam sistem operasi android. Dimana sistem manajemen basis data SQLite ini bukan merupakan sistem basis data yang layanan atau service tidak bersifat pelayanan sebagai server database. Sebaliknya sistem database sesuai dengan arsitekturnya tercantum pada aplikasi final android yang dirancang. Dimana SQLite database ditempatkan pada suatu path atau mount data dalam sistem berbasis android. 


\subsection{Android studio.}

Android studio[7] merupakan perangkat lunak pengembangan platform android yang terintegrasi yang dikembangkan oleh pengembang perangkat lunak yaitu JetBrain dan IntelliJ IDEA, yang mana android studio ini adalah sebuah platform yang terintegrasi untuk perbaikan library dan tools perangkat lunak sebelumnya yaitu Eclipse IDE. Sedangkan bahasa pemrograman yang digunakan menggunakan bahasa jawa, kotlin dan c++.

\subsection{Rapid application development.}

Rapid Application Development (RAD)[8],[9],[10],[11] dalam penelitian tersebut merupakan siklus pengembangan yang bertujuan untuk menyediakan pengembangan perangkat lunak dengan relatif cepat dan dengan mendapatkan hasil pengembangan perangkat lunak dengan kualitas yang lebih baik jika dibandingkan dengan metode siklus tradisional. RAD ini dapat meningkatkan sistem secara signifikan dan membutuhkan waktu pengembangan relatif cepat. Adapun tahapan-tahapan dari pengembangan perangkat lunak menggunakan RAD ini adalah perencanaan syarat-syarat (requirements planning), RAD design Workshop (workshop design $R A D)$ dan implementasi (implementation).

\subsection{UML.}

UML [12][13][14][15] merupakan metode analisis untuk pemodelan desain perancangan yang digunakan oleh developer perangkat lunak pada program berorientasi objek, baik untuk proyek skala kecil menengah maupun besar.

\section{HASIL DAN PEMBAHASAN.}

3.1. Analisis kebutuhan sistem.

a) Petugas kasir bisa melakukan pengelolaan jenis makanan olahan ayam geprek yang tersedia untuk dijual.

b) Petugas kasir dapat melakukan transaksi penjualan ayam geprek dan variannya.

c) Petugas kasir dapat mencetak struk transaksi penjualan pada pelanggan.

d) Petugas kasir dapat membuat rekapitulasi laporan penjualan.

3.2. Kebutuhan fungsional.

a) Aplikasi dapat melakukan perhitungan secara otomatis saat transaksi berjalan, sehingga petugas kasir dan pelanggan dapat mengetahui jumlah transaksi, kemudian petugas kasir dan pelanggan mengetahui berapa total dari pembelian makanan yang dibeli oleh pelanggan.

b) Aplikasi dapat melakukan perhitungan terhadap jumlah makanan yang terjual dan makanan mana yang terjual paling banyak.

c) Aplikasi dapat melakukan pengolahan data transaksi atau pencatatan laporan pendapatan.

d) Aplikasi dapat menambah data makanan, kategori dan harga serta dapat mengubah dan menghapus data makanan sesuai kategorinya.

\subsection{Kebutuhan tambahan non fungsi.}

Aplikasi kasir dalam implementasinya sistem dapat berjalan dalam perangkat smartphone android dengan memanfaatkan sistem database embedded SQLite serta dapat mencetak struk penjualan dengan menggunakan printer Bluetooth portable untuk pelanggan. Sedangkan versi android yang disyaratkan dalam menggunakan aplikasi kasir ini minimal smartphone Android 5.0 dalam implementasinya.

\subsection{Arsitektur aplikasi.}


Dalam perancangan aplikasi kasir ini untuk supaya penganalisis dan pengguna memahami konsep dari perancangan ini menyajikan arsitektur dari aplikasi kasir yang akan dirancang seperti pada gambar 1 .

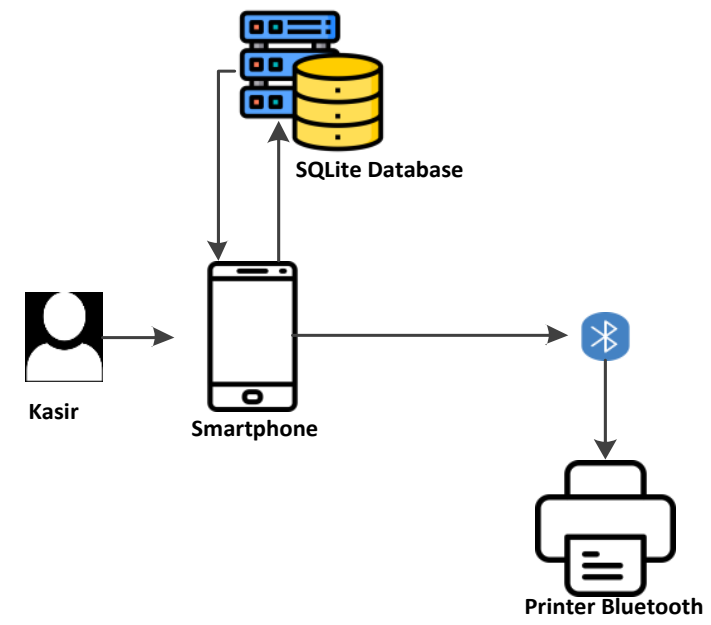

Gambar 1. Arsitektur Aplikasi Kasir.

3.5. Use a case diagram.

Dalam proses analisis perancangan aplikasi kasir ini menggunakan metode UML dan Use case perancangan aplikasi kasir smartphone seperti pada gambar 2 .

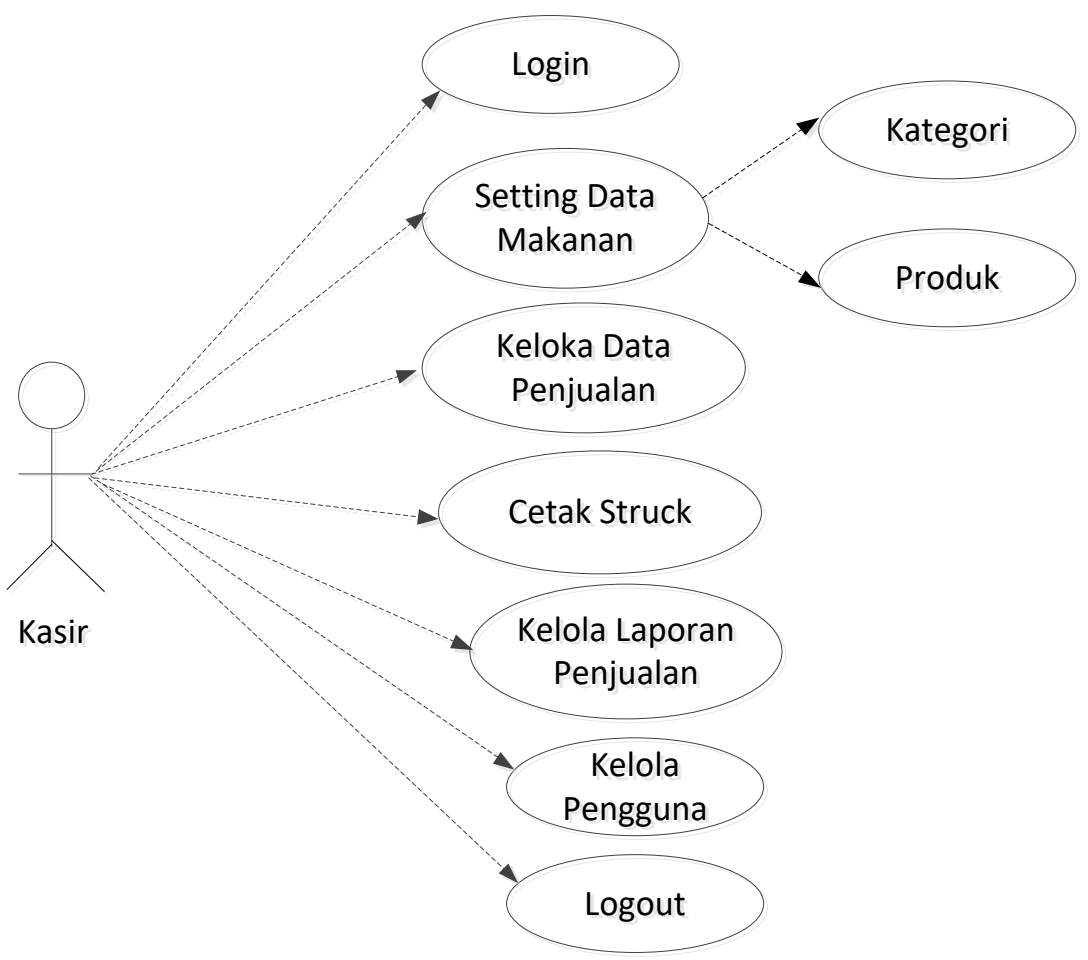

Gambar 2. Use case diagram.

\subsection{Entity relationship diagram.}

Selanjutnya dalam perancangan database terkait dengan tabel-tabel yang berhubungan dalam pembuatan aplikasi kasir terdiri dari tabel kasir, tabel login, tabel penjualan, tabel kategori, tabel pengguna, tabel makanan, tabel detail penjualan. Adapun lebih jelasnya seperti pada entity relationship diagram terlihat pada gambar 3 . 


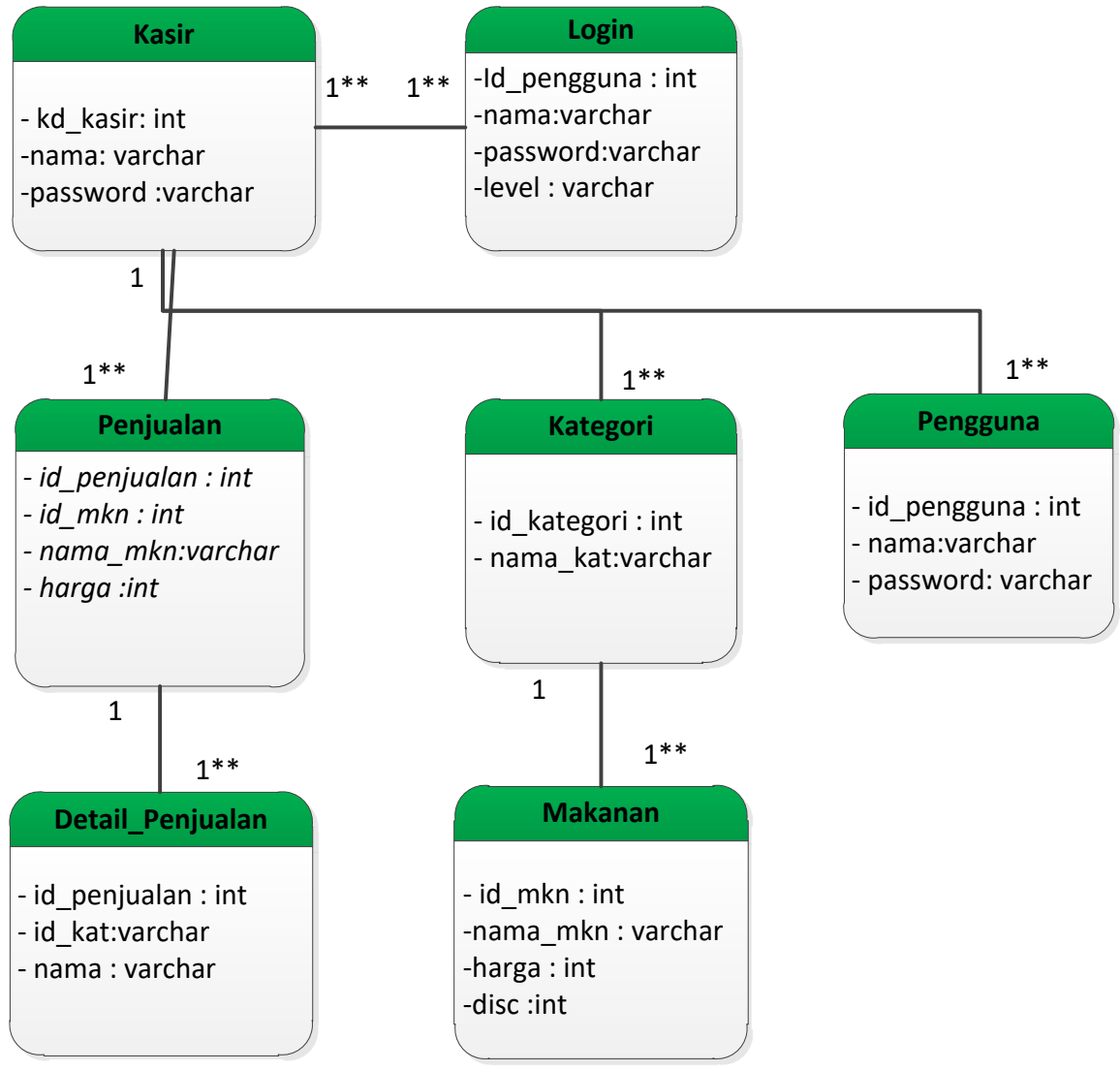

Gambar 3. Entity relationship diagram

3.7. Spesifikasi perangkat hardware dan software (H/W).

Pada tahapan perancangan aplikasi kasir menggunakan $\mathrm{H}$ atau $\mathrm{S}$ dengan spesifikasi, perangkat keras, dan perangkat lunak.

A. Perangkat keras.

1. Desktop.

2. Processor Intel Core i3 $(2.1 \mathrm{GHz})$.

3. RAM 4GB.

4. HDD 1TB.

5. Mobile Android (emulator)

6. Samsung Galaxy J7 Core $(2.1 \mathrm{GHz})$.

7. RAM 2 GB.

8. HDD 16 GB.

B. Perangkat lunak.

1. Sistem OS: Windows 8.164 bit.

2. Bahasa Program: Java

3. Database : SQLite

4. Editor: Android Studio dan Notepad ++

5. API Level Java versi 7: JDK 1.7.

3.8. Implementasi aplikasi

Sebagai interface atau antarmuka dari aplikasi kasir ini menyediakan halaman login, halaman utama, halaman setting untuk kategori, setting model dan order. 


\subsection{Halaman login}

Halaman login ini adalah interface dari pengguna atau kasir sebelum mengoperasikan aplikasi kasir ini, seperti pada gambar 4.

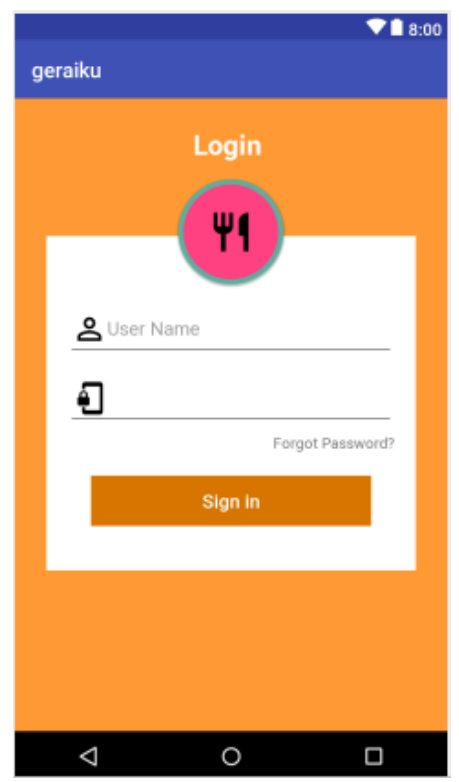

Gambar 4. Halaman login.

\subsection{Halaman utama}

Halaman utama merupakan interface dari pengguna atau kasir dimana pada halaman utama terdapat menu master data, setting, order, report, info dan logout dalam mengoperasikan aplikasi kasir terlihat pada gambar 5 .

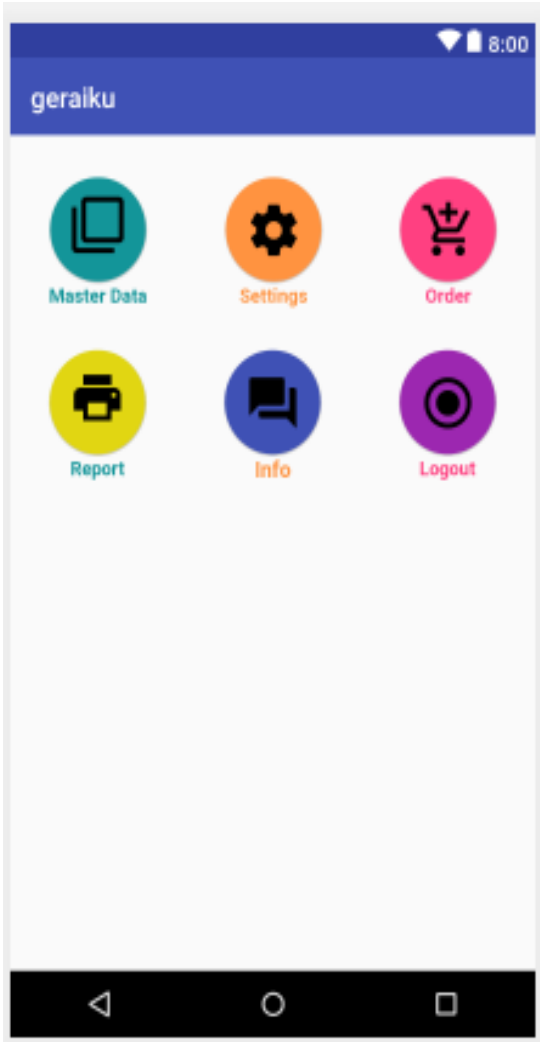

Gambar 5. Halaman utama. 
PERANCANGAN APLIKASI KASIR POINT OF SALES BERBASIS ANDROID MENGGUNAKAN METODE RAPID APPLICATION DEVELOPMENT UNTUK USAHA RETAIL

\subsection{Halaman setting}

Halaman setting merupakan interface dari pengguna atau kasir dalam melakukan setting produk sesuai kategori, menambah jenis produk dan pengguna untuk jelasnya seperti pada gambar 6.

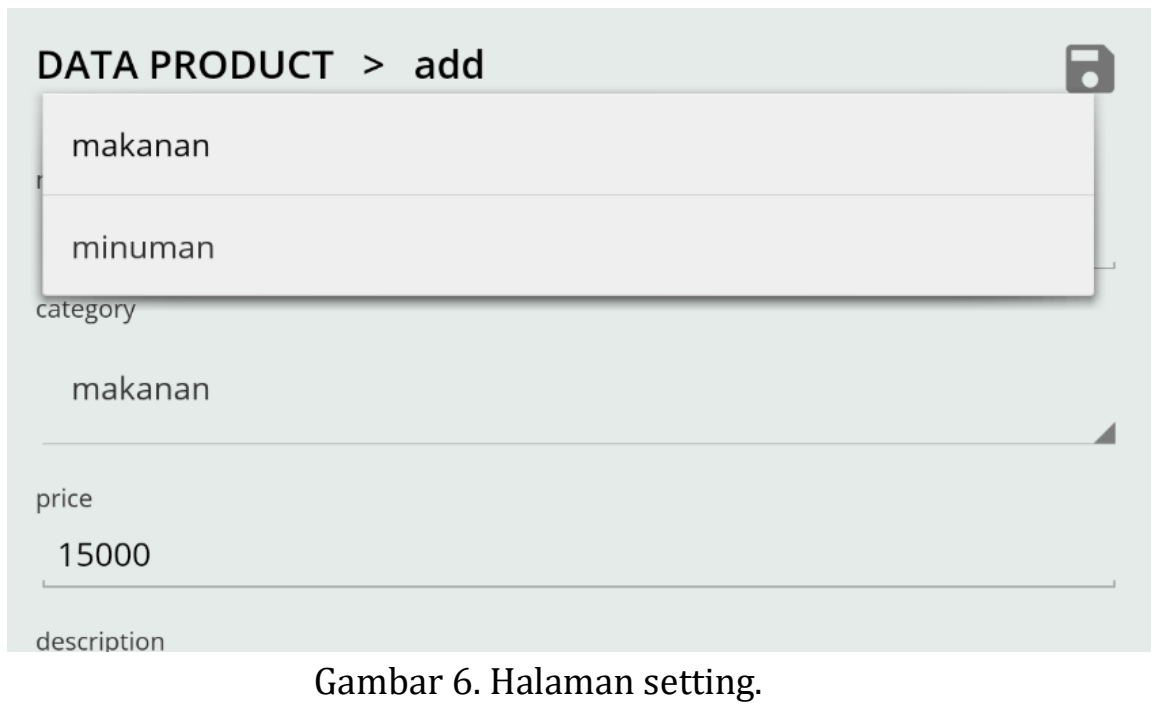

\subsection{Halaman Order}

Halaman order merupakan interface dari pengguna atau kasir dalam melakukan transaksi penjualan dengan pelanggan, untuk lebih jelasnya seperti pada gambar 7 .

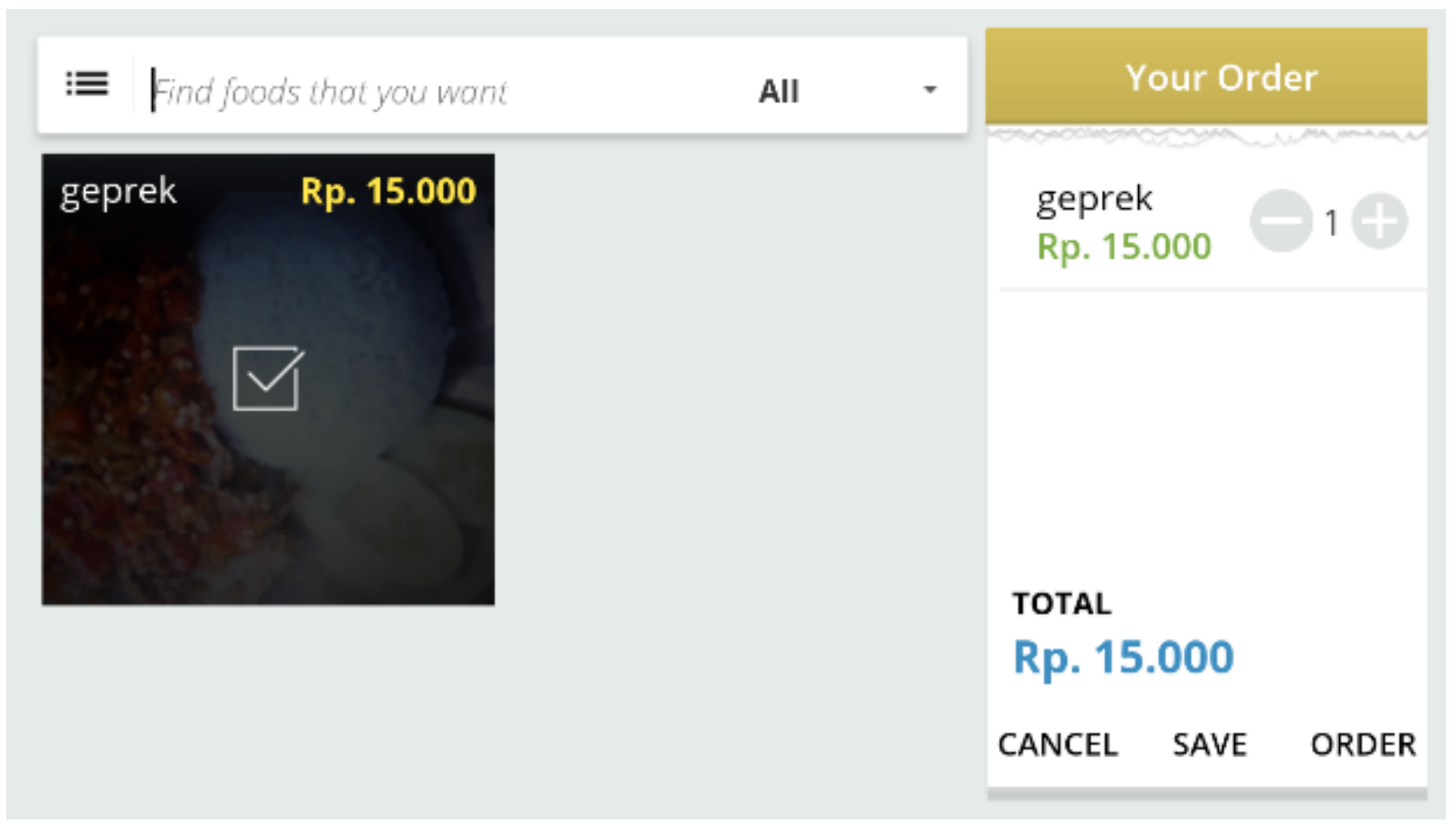

Gambar 7. Halaman transaksi.

\subsection{Halaman report}

Halaman report merupakan interface dari pengguna atau kasir dalam melakukan pencetakan laporan. Selain interface di atas juga terdapat info dari sistem dan logout dari user. 


\subsection{Pengujian sistem}

Dalam memvalidasi kebenaran perancangan dengan tujuan aspek-aspek kebutuhan sistem yang sudah disebutkan dalam kebutuhan fungsional dan non fungsional penganalisis melakukan pengujian pada performance perangkat lunak aplikasi kasir menggunakan perangkat yang diujikan pada tabel 1 .

Tabel 1. Perangkat alat uji coba

\begin{tabular}{cccc}
\hline No. & Nama Smartphone & Android Versi & Hasil \\
\hline 1. & Samsung Galaxy J7 Core & Versi 7.0 & running \\
2. & OPPO3s & Versi 8.1 & running \\
3. & Redmi 5A & Veri 7.0 & running \\
\hline
\end{tabular}

Sebagai hasil dari pengujian aplikasi kasir dengan metode black box testing secara lebih detail dijelaskan pada tabel 2.

Tabel 2. Hasil uji coba black box testing

\begin{tabular}{|c|c|c|c|}
\hline No & $\begin{array}{l}\text { Skenario } \\
\text { pengujian }\end{array}$ & Hasil yang diharapkan & Kesimpulan \\
\hline 1. & Login kasir & $\begin{array}{l}\text { Berhasil login sesuai username } \\
\text { dan password }\end{array}$ & Valid \\
\hline \multirow[t]{8}{*}{2.} & Kasir & $\begin{array}{l}\text { - Bisa menambah kategori } \\
\text { makanan }\end{array}$ & Valid \\
\hline & & $\begin{array}{l}\text { - Bisa menambah makanan, } \\
\text { merubah jenis makanan }\end{array}$ & Valid \\
\hline & & $\begin{array}{l}\text { - Bisa melakukan transaksi } \\
\text { penjualan makanan }\end{array}$ & Valid \\
\hline & & $\begin{array}{l}\text { - Bisa mencetak struk } \\
\text { penjualan }\end{array}$ & Valid \\
\hline & & $\begin{array}{l}\text { - Bisa membuat rekapitulasi } \\
\text { penjualan }\end{array}$ & Valid \\
\hline & & $\begin{array}{l}\text { - Bisa membuat laporan } \\
\text { penjualan }\end{array}$ & Valid \\
\hline & & - Mengatur level pengguna & Valid \\
\hline & & - Menghapus pengguna & Valid \\
\hline \multirow[t]{2}{*}{3.} & Admin & - Menambah kategori & Valid \\
\hline & & $\begin{array}{ll}- & \text { Melakukan } \\
\text { penjualan } & \text { transaksi }\end{array}$ & Valid \\
\hline \multirow[t]{2}{*}{4.} & & - Mencetak struk dan laporan & Valid \\
\hline & Login Admin & $\begin{array}{l}\text { - } \begin{array}{lr}\text { Dapat melakukan login } \\
\text { dengan username }\end{array} \\
\text { password admin }\end{array}$ & Valid \\
\hline
\end{tabular}


Dari hasil pengujian aplikasi kasir, maka performance aplikasi ini dapat digunakan dan dapat bekerja dengan maksimal di versi android mulai versi 7 keatas.

\section{SIMPULAN}

Berdasarkan data hasil penelitian perancangan sistem berbasis android menggunakan metode Rapid Application Development (RAD) menghasilkan aplikasi kasir yang dapat melakukan transaksi penjualan produk makanan sesuai dengan kategori dan membuat laporan transaksi penjualan, selanjutnya dilakukan pengujian performance pada aplikasi tersebut menghasilkan performa yang cukup baik sehingga aplikasi kasir dapat digunakan oleh pengguna.

\section{REFERENSI}

[1] A. Suheryadi et al., "Pengembangan aplikasi mobile pencatatan transaksi penjualan olahan mangga terintegrasi berbasis android," J. Politek. Negeri Bandung, vol. 10, pp. 107-115, 2019.

[2] G. Pamungkas and H. Yuliansyah, "Rancang Bangun Aplikasi Android Pos (Point of Sale) Kafe Untuk Kasir Portable Dan Bluetooth Printer," JST (Jurnal Sains dan Teknol., vol. 6, no. 1, pp. 199-208, 2017.

[3] D. Muheri, "Rancang Bangun Aplikasi Point Of Sale Berbasis Android (Studi Kasus: Sekolah Darma Yudha)," Pros. Semin. Nas. Comput. Technol. its Apl., pp. 11-15, 2019.

[4] M. Siddik and S. Samsir, "Rancang Bangun Sistem Informasi Pos (Point of Sale) Untuk Kasir Menggunakan Konsep Bahasa Pemrograman Orientasi Objek," JOISIE (Journal Inf. Syst. Informatics Eng., vol. 4, no. 1, p. 43, 2020.

[5] R. Singh, "An Overview of Android Operating System and Its Security Features," Eng. Res. Appl., vol. 4, no. 2, pp. 519-521, 2014.

[6] S. T. Bhosale, T. Patil, and P. Patil, "SQLite: Light Database System," Int. J. Comput. Sci. Mob. Comput., vol. 44, no. 4, pp. 882-885, 2015.

[7] W. Pribadi, R. E. Masithoh, A. P. Nugroho, and Radi, "Development of android-based interface to determine color additives in food embedded with convolution neural networks technique," IOP Conf. Ser. Earth Environ. Sci., vol. 355, no. 1, 2019.

[8] T. Wahyuningrum and D. Januarita, "Perancangan Web e-Commerce dengan Metode Rapid Application Development ( RAD ) untuk Produk Unggulan Desa," vol. 2014, no. November, pp. 81-88, 2014.

[9] J. R. Sagala, "Model Rapid Application Development (Rad) Dalam Pengembangan Sistem Informasi Penjadwalan Belajar Mengajar," J. Mantik Penusa, vol. 2, no. 1, pp. 87-90, 2018.

[10] S. Aswati and Y. Siagian, "Model Rapid Application Development Dalam Rancang Bangun Sistem Informasi Pemasaran Rumah (Studi Kasus: Perum Perumnas Cabang Medan," Sesindo, pp. 317-324, 2016.

[11] S. A. Putri and E. P. Saputra, "Perancangan Aplikasi Sistem Pakar Diagnosa Awal Kanker Reproduksi Wanita Dengan Metode Certainty Factor," J. Media Inform. Budidarma, vol. 2, no. 3, pp. 63-68, 2018.

[12] M. Gogolla and F. Hilken, "Model validation and verification options in a contemporary UML and OCL analysis tool," Lect. Notes Informatics (LNI), Proc. - Ser. Gesellschaft fur Inform., vol. P254, pp. 205-220, 2016.

[13] E. Nazaruka, "Meaning of cause-And-effect relations of the topological functioning model in the UML analysis model," ENASE 2017 - Proc. 12th Int. Conf. Eval. Nov. Approaches to Softw. Eng., no. Enase, pp. 336-345, 2017. 
[14] A. Yudhana, Sunardi, and Priyatno, "Perancangan Pengaman Pintu Rumah Berbasis Sidik Jari Menggunakan Metode Uml,” J. Teknol., vol. 10, no. 2, pp. 131-138, 2018.

[15] I. Nugroho, H. Listiyono, and sariyun naja Anwar, "Perancangan Unified Modelling Language aplikasi Sarana Prasarana Pendukung Pariwisata Kota Semarang," Proceeding SENDI, vol. 2, no. 1, pp. 90-95, 2017. 